Original Article

\title{
Assessment of biochemical profile among patients of Microbiological Quality Assessment of Bakery Products Available in Lahore, Pakistan
}

Anil Gill ${ }^{1}$, Akash John ${ }^{2}$,Neelam Iqbal ${ }^{3}$, Tallat Anwar Faridi ${ }^{4 *}$ and Sofia Noor ${ }^{4}$

${ }^{1}$ Gujranwala Institute of Medical and Emerging Sciences, Gujranwala, Pakistan

${ }^{2}$ University Institute of Radiological and Medical Imaging Sciences, The University of Lahore, Gujrat Campus, Gujrat, Pakistan

${ }^{3}$ Institute of Molecular Biology and Biotechnology, The University of Lahore, Lahore, Pakistan

${ }^{4}$ University Institute of Public Health, The University of Lahore, Lahore, Pakistan

Keywords: Bakery products, Microbial assessment, Coliform bacteria, Fecal Coliform bacteria, Yeast.

\section{How to Cite:}

Gill, A. ., John, A. ., Iqbal, N. .

Faridi, T. A. ., \& Noor, S.

(2020). Assessment of

biochemical profile among

patients of Microbiological

Quality Assessment of Bakery

Products Available in Lahore,

Pakistan: Microbiological

Quality Assessment of Bakery

Products Available in Lahore,

Pakistan. DIET FACTOR

(Journal of Nutritional \&Amp;

Food Sciences), 1(01), 19-23.

https://doi.org/10.54393/df.v1i0 1.1

Corresponding author:

Tallat Anwar Faridi

Faculty of Allied Health

Sciences, The University of

Lahore, Lahore, Pakistan

tallatanwar@pht.uol.edu.pk

\section{Article History}

Received: $15^{\text {th }}$ May 2020

Accepted: $17^{\text {th }}$ June 2020

Published: $30^{\text {th }}$ June 2020

\section{ABSTRACT}

Bakery items are a vital element of a well-balanced diet, and supermarket shelves now stock a wide range of them. Bakery items are the most popular ready-to-eat foods (REF). Objective: To assess the microbial quality of bakery foods (Bread, Cake and patties) and check the total plate count (TPC), bacterial and yeast count Methods: The analysis of the microbial quality of bakery products was determined for three different bakery products (bread, cake and patties) at ten different locations collected from a renowned bakery in Lahore, Pakistan. The samples were assessed under complete hygienic conditions by standardized plate count (TPC) and MPN method. Microorganisms (Coliform, Fecal Coliform and Yeast) were lately confirmed by their morphological characteristics and biochemical tests Results: Among the three commodities, bread was found to be highly contaminated by micro-organisms and the total plate count recorded was $4.7 \times 10^{5} \mathrm{cfu} \mathrm{g}^{-1}$ collected from sector $\mathrm{I} 9$ which is not consumable. Whereas Patties showed the number of TPC as $1.6 \times 10^{5} \mathrm{cfu} \mathrm{g}^{-1}$ also collected from sector 19. Cake was revealed as least infected bakery product i.e., $5.7 \mathrm{x}$ $10^{4} \mathrm{cfu} \mathrm{g}^{-1}$. The above results showed that sector I9 is highly contaminated and a threat for health. Bacterial plate count (Coliform and Fecal Coliform count) was highly measured in bread as $460 \mathrm{MPN} \mathrm{g}^{-1}$ taken from sector 5 where as it remains under the permissible limit determined by WHO, 1994 in remaining sectors Conclusions: In conclusion the bakery food is contaminated by the use of un-hygienic water, miss handled during the process after baking i.e., slicing, serving and packaging. To avoid a possible epidemic of food borne illness, competent authorities should conduct a stricter and more stringent inspection of REFs sold to clients in bakeries.

\section{INTRODUCTION}

Bakery items are a vital element of a well-balanced diet, and supermarket shelves now stock a wide range of them[1]. This comprises of sweet goods (pancakes, doughnuts, waffles and cookies), unsweetened goods (bread, rolls, buns, crumpets, muffins and bagels) and filled goods (fruit and meat pies, sausage rolls, pastries, sandwiches, cream cakes, pizza and quiche)[2]. Various studies in both developed and developing countries revealed that bakery products provide a considerable portion of energy intake $[3,4]$.

Secernated from the quickly biodegradable bakery products are cake, bread and biscuits. These products are distributed over a wider range of area from manufacturing industry[5]. Microorganisms play an essential and useful role in the production of bakery products[6] (formation of flavoring, consistency); However, microorganisms also attack bakery products and 
damage or change the constituency of the product and even spoilage[7]

The majority of consumers who utilize these eatable services are more concerned with their comfort rather than the microbiological standards and cleanliness[8]. The amount/potential of microbial contaminants in food is determined by microbiological quality assessment; a high degree of contamination implies poor food storage [9] and handling, making it more prone to spread diseases, and vice versa[10]. As a result, the Food and Agricultural Organization (FAO) has expressed worry that these foods could be a major source of food poisoning outbreaks[11]. More than 200 known diseases are caused because of contaminated food[12].

Molds and yeasts, in addition to bacteria, are the most common causes of food spoilage. Freshly baked goods are sterile and free of living germs, but they quickly get contaminated when exposed to air and surfaces[13]. Contamination also occurs, after baking process, during the production steps such as cooling, slicing (unhygienic handling), transport, and packing as well as storage[14]. Within this production and storage chain, the bakery products are contaminated with moulds, yeasts and occasionally by bacteria such as the rope-causing heat resistant endospore-forming Bacillus subtilis[15]Because mould spores are killed during the baking process, contamination is often the root of spoiling issues[16].

Water activity is the most important single element impacting the kind and pace of deterioration in many baked products[17]. Microorganisms (bacteria, yeast and mould) can reproduce well when water activity or moisture content is high [18].

Yeast may also be involved in spoilage of breads and fruitcakes, resulting in a chalky appearance on surfaces and off odors[19]. Increased sugar content of cake also favors moulds over other spoilage microbes but some species of yeasts and bacteria may also infect cakes.

Bakery products carrying cream or fruit filling are targets of other spoilage organisms[18]E. coli0157 has been considered to be a significant pathogen that can cause severe illness. It is a typical organism of the intestinal tract; it is transmitted through contaminated hands and is recorded to be the cause of diarrhea[20].

\section{METHODS}

\section{Sample Collection}

A sum of 30 samples comprising of ten each of three ready to eat foods (RET) i.e., bread, cake and patties were obtained from one renowned food bakery located at 10 different areas of Lahore. The samples were collected in a time span of 6 months period from September 2019 to March 2020. Samples were purchased and transported by maintaining the cold chain under aseptic conditions for quality assessment of microorganisms within one hour of collection.

\section{Microbiological analysis}

Samples were assessed in triplicates. Total plate count, coliform, fecal coliform and yeast were analyzed.

\section{Preparation of dilutions}

Samples were homogenized with Butterfield's phosphate buffer (pH 7.2). 10 gram of every food sample was mixed with $90 \mathrm{ml}$ of Butterfield's phosphate buffer, and serial dilutions of each homogenate food samples were prepared up to $10^{-5}$ dilutions.

\section{Inoculation and incubation}

$1 \mathrm{ml}$ aliquot volumes were transferred to petri dishes with plate count agar and mixed with medium. After inoculation of samples, they are incubated at $35^{\circ} \mathrm{C}$ for 48 hours and the colonies become visible inside and on the surface of medium after $48^{\circ}$ hours. The colonies were counted with a colony counter (Gallenkamp, England), and the counts were expressed as colony forming colony forming unit per gram of homogenate sample (cfu g-1). The colonies' various morphological characteristics were pragmatically recorded. Numerous sub-culturings were used to isolate and purify separate colonies. For subsequent testing, the pure culture was kept on slants at $4^{\circ} \mathrm{C}$.

\section{Coliform/ Fecal Coliform test}

In the MPN method,presumptive test is conducted first. Each sample was divided into one (1) gram portions and placed in sterile McCartney bottles containing Lactose broth and inverted Durham tubes. At $37^{\circ} \mathrm{C}$, the cells were incubated for $24-48$ hours. EMB plates were streaked with tubes that showed gas production and/or dye color shift.Colonies from EMB plates were picked and inoculated into tubes containing lactose broth for the completed test and onto Nutrient agar slants for further characterization and incubated for $37^{\circ} \mathrm{C}$ for 24 hours. 


\section{Identification of isolates}

The bacterial isolates were recognized on the basis of various cultural characteristics and biochemical tests. The yeast identification was completed by macroscopic and microscopic characteristics.

\section{Bacterial identification}

Standard microbiological procedures were used to identify the bacterium isolates. As a preliminary test, the following cultural features and biochemical tests were performed: catalase, IMViC test, coagulase, phosphatase production, motility, Oxidase, and Urease production.

\section{Yeast identifications}

Isolated yeast was poured on plate count agar with added chloramphenicol (added as anti-bacterial agent). Petri plates were incubated at $25^{\circ} \mathrm{C}$ for 3 to 5 days. Then the isolates were stained by Methylene blue and observed under microscopes.

\section{Data assessment}

The data obtained for total aerobic plate count, coliform, fecal Coliform and yeast counts were subjected to assessment of variance.

\section{RESULTS}

Different samples of bread, cake and patties are collected from 10 different areas of city Lahore and tested for microbiological assessment. Under hygienic conditions it has been transferred from the bakeries to the laboratory, Where it under go presumptive test, firstly, followed by confirmatory tests.

According to WHO standard (1994) the maximum permissible limits in baked products (cake, bread and biscuits) for total plate count (TPC) is 2.0x105 cfu g-1, Coliform bacteria <200 MPN g-1, yeast and mould is <1.0x104 cfu g-1. Results are expressed as mean value of 3 samples (Table 1).

Maximum total plate count was recorded in bread in samples received from I9 as $4.7 \mathrm{x} 105 \mathrm{cfu}$ g-1which is more than the acceptable limit. Bread had also showed the maximum Coliform and fecal Coliform Bacterial count as 450 MPN g-1, which is more than twice of the permissible limit determined. Least plate count for bread was recorded in I5 i.e., $5.5 \mathrm{x} 103 . \mathrm{cfu}$ g1. Other bacterial counts recorded are within the acceptable range. Yeast recorded in bread was highest in I7 i.e., $500 \mathrm{cfu}$ g-1(Figure 1).Highest plate count for patties was recorded as 1.6 x $105 \mathrm{cfu}$ g-1 collected from I9 which is not consumable and above permissible limits. Other bacterial plate counts are within range and less than 200 MPN g-1. Samples received from all other areas (I1 to I8 and I10) revealed less than permissible limits. Yeast was recorded in a very little amount which is negligible (Figure 2).

Samples of cake obtained from different bakeries recorded the maximum number of total plate count as 5.7 x $104 \mathrm{cfu}$ g-1 collected from I2. All the samples show results with in the permissible range. For other bacterial and yeast count, it again showed amount with in the acceptable limits (Figure 3).

Samples collected from I2 to I8 and I10 were fit for consumption as their TPC, Coliform, Fecal Coliform and Yeast was within the permissible limits. Total plate count TPC for bread obtained from I2 and I9 were higher than the acceptable limits, therefore, not good for consumption. It's Coliform and fecal Coliform also exceeds form its limits and recorded as more than twice in I5.

\begin{tabular}{|c|c|c|c|c|c|}
\hline Sector & Commodity & $\begin{array}{l}\text { TPC } \\
\text { (cfu g-1) }\end{array}$ & $\begin{array}{l}\text { Coliform } \\
\left(\text { MPN g }^{-1}\right)\end{array}$ & $\begin{array}{l}\text { Fecal Coliform } \\
\left(\text { MPN g }^{-1}\right)\end{array}$ & $\begin{array}{l}\text { Yeast } \\
\left.\text { (cfu g }^{-1}\right)\end{array}$ \\
\hline I1 & $\begin{array}{l}\text { Bread } \\
\text { Cake } \\
\text { Patties } \\
\end{array}$ & $\begin{array}{l}2.8 \times 10^{5} \\
2.7 \times 10^{4} \\
8.7 \times 10^{4}\end{array}$ & $\begin{array}{l}<3 \\
<2 \\
9\end{array}$ & $\begin{array}{l}<3 \\
<3 \\
9\end{array}$ & $\begin{array}{l}250 \\
\text { Nil } \\
\text { Nil } \\
\end{array}$ \\
\hline 12 & $\begin{array}{l}\text { Bread } \\
\text { Cake } \\
\text { Patties }\end{array}$ & $\begin{array}{l}2.8 \times 10^{4} \\
5.7 \times 10^{4} \\
2.7 \times 10^{3}\end{array}$ & $\begin{array}{l}11 \\
75 \\
28\end{array}$ & $\begin{array}{l}11 \\
23 \\
12\end{array}$ & $\begin{array}{l}\mathrm{Nil} \\
\mathrm{Nil} \\
\mathrm{Nil}\end{array}$ \\
\hline
\end{tabular}




\begin{tabular}{|c|c|c|c|c|c|}
\hline 13 & $\begin{array}{l}\text { Bread } \\
\text { Cake } \\
\text { Patties }\end{array}$ & $\begin{array}{l}7.7 \times 10^{4} \\
7.1 \times 10^{3} \\
3.4 \times 10^{4}\end{array}$ & $\begin{array}{l}9 \\
4 \\
23\end{array}$ & $\begin{array}{l}9 \\
2 \\
21\end{array}$ & $\begin{array}{l}\mathrm{Nil} \\
\mathrm{Nil} \\
\mathrm{Nil}\end{array}$ \\
\hline 14 & $\begin{array}{l}\text { Bread } \\
\text { Cake } \\
\text { Patties }\end{array}$ & $\begin{array}{l}3.6 \times 10^{4} \\
3.4 \times 10^{4} \\
4.4 \times 10^{4}\end{array}$ & $\begin{array}{l}<3 \\
9 \\
<3\end{array}$ & $\begin{array}{l}<3 \\
9 \\
<3\end{array}$ & $\begin{array}{l}\mathrm{Nil} \\
\mathrm{Nil} \\
\mathrm{Nil}\end{array}$ \\
\hline 15 & $\begin{array}{l}\text { Bread } \\
\text { Cake } \\
\text { Patties } \\
\end{array}$ & $\begin{array}{l}5.5 \times 10^{3} \\
3.3 \times 10^{4} \\
5.8 \times 10^{3}\end{array}$ & $\begin{array}{l}460 \\
15 \\
9\end{array}$ & $\begin{array}{l}460 \\
15 \\
7 \\
\end{array}$ & $\begin{array}{l}\mathrm{Nil} \\
\mathrm{Nil} \\
\mathrm{Nil}\end{array}$ \\
\hline 16 & $\begin{array}{l}\text { Bread } \\
\text { Cake } \\
\text { Patties } \\
\end{array}$ & $\begin{array}{l}3.6 \times 10^{4} \\
3.7 \times 10^{4} \\
4.4 \times 10^{4}\end{array}$ & $\begin{array}{l}<3 \\
9 \\
23\end{array}$ & $\begin{array}{l}<3 \\
9 \\
23\end{array}$ & $\begin{array}{l}\mathrm{Nil} \\
\mathrm{Nil} \\
\mathrm{Nil}\end{array}$ \\
\hline 17 & $\begin{array}{l}\text { Bread } \\
\text { Cake } \\
\text { Patties }\end{array}$ & $\begin{array}{l}7.7 \times 10^{4} \\
8.1 \times 10^{3} \\
3.4 \times 10^{4}\end{array}$ & $\begin{array}{l}23 \\
4 \\
9\end{array}$ & $\begin{array}{l}23 \\
4 \\
9\end{array}$ & $\begin{array}{l}500 \\
\mathrm{Nil} \\
\mathrm{Nil}\end{array}$ \\
\hline 18 & $\begin{array}{l}\text { Bread } \\
\text { Cake } \\
\text { Patties }\end{array}$ & $\begin{array}{l}3.6 \times 10^{4} \\
3.7 \times 10^{4} \\
4.4 \times 10^{4}\end{array}$ & $\begin{array}{l}<3 \\
9 \\
21\end{array}$ & $\begin{array}{l}<3 \\
9 \\
21\end{array}$ & $\begin{array}{l}50 \\
\mathrm{Nil} \\
\mathrm{Nil}\end{array}$ \\
\hline 19 & $\begin{array}{l}\text { Bread } \\
\text { Cake } \\
\text { Patties }\end{array}$ & $\begin{array}{l}4.7 \times 10^{5} \\
5.5 \times 10^{4} \\
1.6 \times 10^{5}\end{array}$ & $\begin{array}{l}23 \\
21 \\
<3\end{array}$ & $\begin{array}{l}23 \\
21 \\
<3\end{array}$ & $\begin{array}{l}250 \\
\text { Nil } \\
\text { Nil }\end{array}$ \\
\hline I10 & $\begin{array}{l}\text { Bread } \\
\text { Cake } \\
\text { Patties }\end{array}$ & $\begin{array}{l}7.7 \times 10^{4} \\
8.1 \times 10^{3} \\
3.4 \times 10^{4}\end{array}$ & $\begin{array}{l}23 \\
4 \\
9\end{array}$ & $\begin{array}{l}23 \\
4 \\
9\end{array}$ & $\begin{array}{l}300 \\
\mathrm{Nil} \\
\mathrm{Nil}\end{array}$ \\
\hline
\end{tabular}

Permissible limits of bakery products: colony count, $<2.0 \times 10^{5} \mathrm{~g}^{-1}$, Coliform count, $<200 \mathrm{~g}^{-1}$, yeast count, $<1.0 \times 10^{4} \mathrm{~g}^{-1}$ (WHO, 1994)

Table 1: Microbial contamination in bakery foods available in Lahore

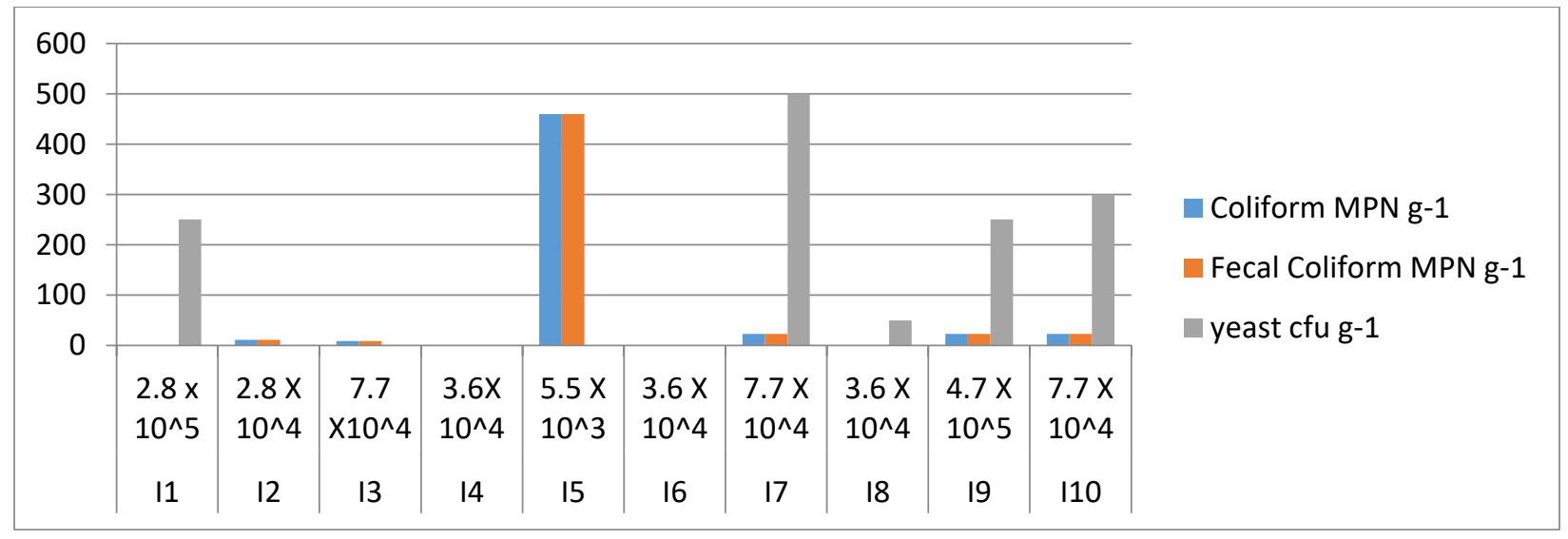

Figure 1: Bacterial count and yeast count for bread samples collected from 10 different sectors

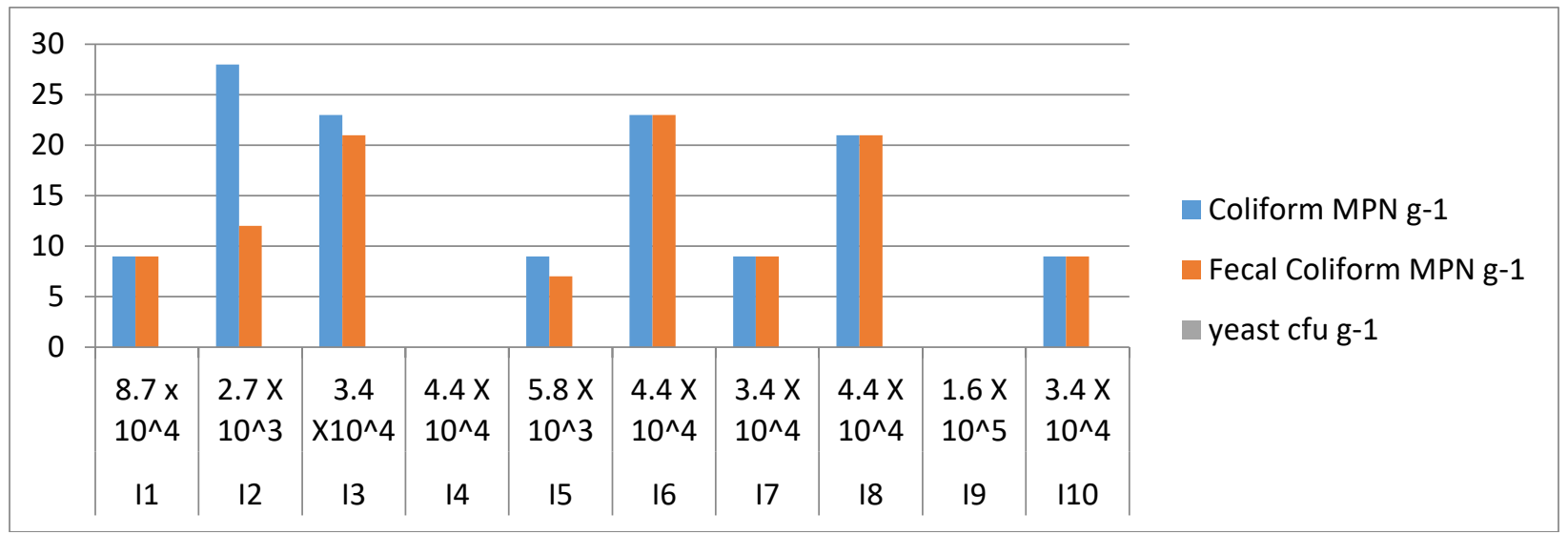

Figure 2: Bacterial count and yeast count for patties samples collected from 10 different sectors 


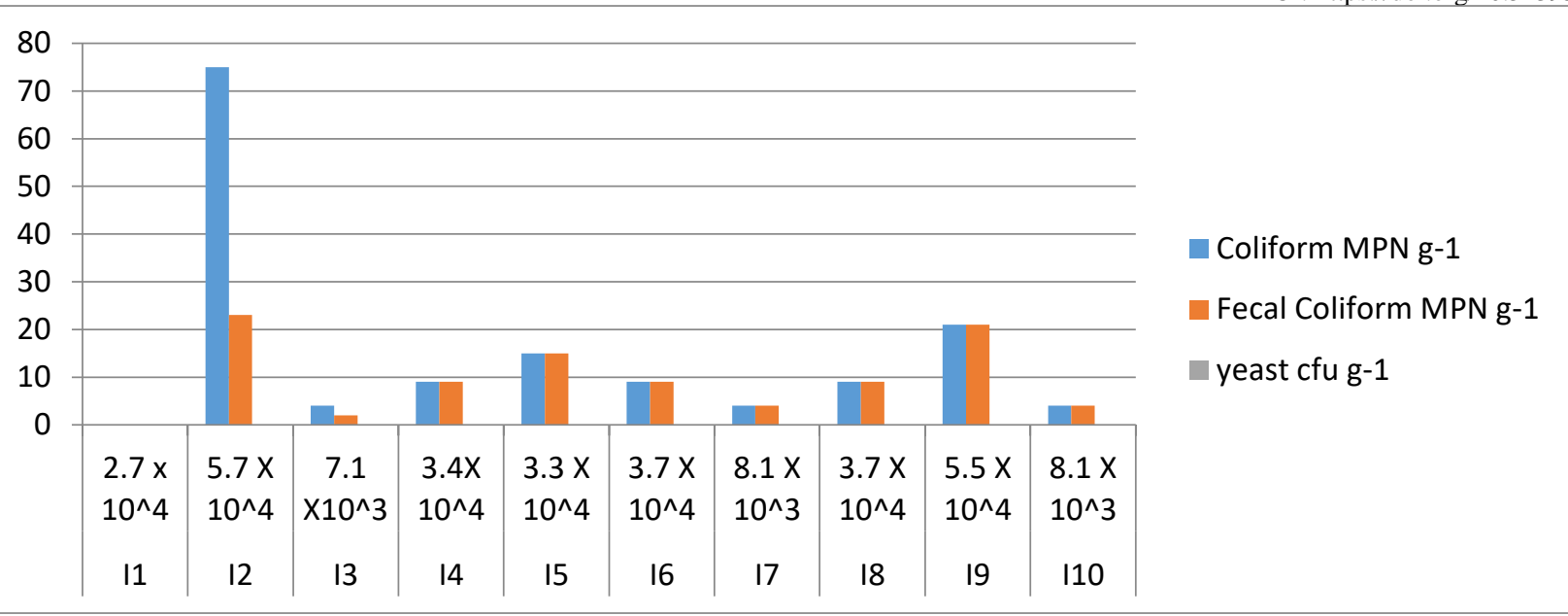

Figure 3: Bacterial count and yeast count observed in cake samples collected from 10 different sectors

\section{DISCUSSION}

Over all the TPC was higher only in two samples I2 and I9 Coliform and fecal Coliform also become higher in I5 once. Most of the time, yeast is barely noticeable. Temperature abuse and poor hygiene measures by the vendors may have resulted in unacceptably high bacteria levels.[21].The $\mathrm{pH}$ of bakery items was found to range between 4.94 and 6.00; with bread (43.8) having the highest moisture content and biscuits have the lowest (3.00).

Chemical profiles such as water activity, $\mathrm{pH}$, and moisture content have been found to be the most critical determinants influencing microbiological quality. Higher moisture content products are more likely to cause foodborne illness because they promote the growth of a wide range of bacteria, yeast, and other fungus species.Bakery items with high moisture content or low acid content provide an ideal habitat for pathogenic bacteria to thrive. The growth of spoilage organisms such as osmophilic yeasts and mould is usually limited to intermediate moisture products. [1].

\section{CONCLUSIONS}

Results obtained from the present research revealed that bread was the most contaminated bakery product rather than cake and patties. Coliform and fecal Coliform bacteria are responsible for contamination which indicates that it may get infected because of the water consumed from the Unhygienic sources. It might have been contaminated in the process of baking, slicing and packaging or it might have resulted by miss handling during serving by the bakery worker.

\section{REFERENCES}

1. Koukoutsis $\mathbf{J}$ et al. In vitro studies to control the growth of microorganisms of spoilage and safety concern in high moisture, high pH bakery products. J. food saf., 2004. 24(3): 211-230 doi.org/10.1111/j.1745-4565.2004.tb00385.x.

2. Pina-Pérez, M.C., et al.,Antimicrobial potential of macro and microalgae against pathogenic and spoilage microorganisms in food. Food chemistry, 2017. 235: 34-44 doi.org/10.1016/j.foodchem.2017.05.033.

3. Rodríguez-Artalejo $\mathrm{F}$ et al. Consumption of bakery products, sweetened soft drinks and yogurt among children aged 67 years: association with nutrient intake and overall diet quality. British J. Nutri., 2003. 89(3): . 419-428 doi: doi.org/10.1079/BJN2002787.

4. Santaliestra-Pasias A, et al. Effect of two bakery products on short-term food intake and gut-hormones in young adults: a pilot study. Int. J. food Sci.Nutr., 2016. 67(5): 562-570 doi.org/10.1080/09637486.2016.1180348.

5. Zakharchenko S, Sperling E and Ionov L. Fully biodegradable self-rolled polymer tubes: a candidate for tissue engineering scaffolds. Biomacromolecules, 2011. 12(6): 2211-2215 doi.org/10.1021/bm2002945.

6. Madrigal $\mathrm{C}$ et al. Energy intake, macronutrient profile and food sources of spanish children aged one to $<10$ yearsresults from the EsNuPI Study. Nutrients, 2020. 12(4): . 893. doi.org/10.3390/nu12040893.

7. Beloglazova $\mathrm{K}$ et al. The effect of biodegradable polymer packaging on the quality of bakery products. Research Journal of Pharmaceutical, Biological and Chemical Sciences, $2019 . \quad 10(2): \quad 747-752$. https://zenodo.org/record/2604235\#.YRJ7ShQzbIU 
8. Varga, L., Microbiological quality of commercial dairy products. 2007. https://www.semanticscholar.org/paper/Microbiological-quality-of-commercial-dairyarga/560869d259ffd8e305a075a2f29541a2b0cab5c8

9. Manea L et al. Overview on the microbiological quality of some meat products with impact on the food safety and health of people. in 2017 E-Health and Bioengineering Conference (EHB). 2017. ieee doi:10.1109/ehb.2017.7995372.

10. Control CfD and Prevention, Vital signs: incidence and trends of infection with pathogens transmitted commonly through food--foodborne diseases active surveillance network, 10 US sites, 1996-2010. MMWR. Morbidity and mortality weekly report, 2011. 60(22): p. 749-755.

11. Adjrah Y et al. Socio-economic profile of street food vendors and microbiological quality of ready-to-eat salads in Lomé. Intl. Food Res. J., 2013. 20(1): . 65.

12. Pérez-Rodríguez $\mathrm{F}$ et al. Evaluation of hygiene practices and microbiological quality of cooked meat products during slicing and handling at retail. Meat science, 2010. 86(2): . 479-485 doi.org/10.1016/j.meatsci.2010.05.038.

13. Ballester-Sánchez, J., et al.,Development of healthy, nutritious bakery products by incorporation of quinoa. Foods, 2019. 8(9): 379 doi.org/10.3390/foods8090379.

14. Todd, E.C., Epidemiology of foodborne diseases: a worldwide review. W. hlth. stat. quart. 1997; 50 (1-2): 30-50, 1997. https://pubmed.ncbi.nlm.nih.gov/9282385/

15. Das K, Sarkar A and Hossain A. Isolation of pathogenic microorganisms and determination of their antibiotic resistance patterns collected from different bakery products of Dhaka city. Food Research, 2020. 4(4): 1312-1316. doi:10.26656/fr.2017.4(4).400

16. O'Brien SS. Bacterial contamination of commercial yeast. 2004, Faculty of Science, University of the Witwatersrand.

17. Abdullah N, Nawawi A and Othman I. Fungal spoilage of starch-based foods in relation to its water activity (aw). Journal of Stored Products Research, 2000. 36(1): 47-54. doi.org/10.1016/S0022-474X(99)00026-0.

18. Syamaladevi RM et al.Influence of water activity on thermal resistance of microorganisms in low-moisture foods: a review. Comprehensive Reviews in Food Science and Food Safety, 2016. 15(2): 353-370. doi.org/10.1111/15414337.12190.

19. Deng L.-Z. et al., Recent advances in non-thermal decontamination technologies for microorganisms and mycotoxins in low-moisture foods. Trends in Food Science \& Technology, 2020. doi.org/10.1016/j.tifs.2020.10.012.

20. Meng $\mathbf{J}$ et al.Enterohemorrhagic Escherichia coli.Food microbiology: Fundamentals and frontiers, 2012: 287-309 doi.org/10.1128/9781555818463.ch12.

21. Zealand AN. Food Standards Australia New Zealand. 2009. 